\title{
THE PUBLIC POLICY (ORDRE PUBLIC) RULE OF THE EU SUCCESSION REGULATION AND THE HUNGARIAN INHERITANCE LAW
}

\author{
Dr. Csöndes Mónika, PhD \\ Corvinus University of Budapest, Business School \\ Budapest, Fővám tér 8., Hungary \\ monika.csondes@uni-corvinus.hu
}

\begin{abstract}
The EU Succession Regulation declares in Article 35 that "[t] he application of a provision of the law of any State specified by this Regulation may be refused only if such application is manifestly incompatible with the public policy (ordre public) of the forum". This paper aims at analysing on the one hand the public policy (ordre public) rule of the EU Succession Regulation and on the other hand the Hungarian inheritance law with regard to the application of Article 35.
\end{abstract}

Keywords: EU Succession Regulation, applicable law, public policy, Hungarian inheritance law, preliminary question

\section{INTRODUCTION}

Courts are sometimes confronted with concepts and rules of foreign law which are considered to violate the fundamental principles of the forum. It occurs when the application of foreign law (the content of its provision) may be contrary to the public policy of the forum. Or, when a decision given in a State wanted to be recognised in another State, and such recognition would be manifestly contrary to the public policy of the State in which recognition is sought.

This paper is based on the presentation held at the conference "Accomplishments, aspects and perspectives - inheritance law in the EU”. 15th anniversary of Inheritance Act of the Republic of Croatia, $2003-2018$ at the Faculty of Law, J.J. Strossmayer University of Osijek on 26th October 2018

** The work and research made by filling out the questionnaire 'Governing Inheritance Statutes after the Entry into Force of EU Succession Regulation - GoInEU' of the EU Justice Programme 2014-2020 coordinated by the University of Florence - in which among others Eötvös Loránd Tudományegyetem of Hungary is also participating - was utilized to the presentation held at the conference in Osijek and to this paper, as well 
This paper aims at analysing the public policy (ordre public) rule of the EU Succession Regulation ${ }^{1}$ and the Hungarian inheritance law. As in case the applicable law is a foreign law, then in certain circumstances the question shall be answered whether the rule of the foreign law (a given foreign law solution) could be considered as contrary to the Hungarian public policy. The analysis focuses on the rules and national traditions of the Hungarian inheritance law.

\section{THE DETERMINATION OF THE APPLICABLE LAW UNDER THE EU SUCCESSION REGULATION}

The EU Succession Regulation is universal in its nature because Article 20 lays down that any law specified by the regulation shall be applied whether or not it is the law of a Member State.

To the question of public policy, it is materiel to sum up the main rules on the determination of the applicable law under the EU Succession Regulation. In the absence of choice, according to Article 21, the habitual residence (in lieu of nationality) is the relevant connecting factor. So, the law applicable to succession as a whole is the law of the country where the deceased was habitually resident at the time of death. As Recital 23 of the Preamble states, the place of habitual residence represents a genuine link between the succession and a State, and declares that the habitual residence thus determined should reveal a close and stable connection with the State concerned. Therefore, Recital 23 of the Preamble addresses the followings to the authorities: „the authority dealing with the succession should make an overall assessment of the circumstances of the life of the deceased during the years preceding his death and at the time of his death, taking account of all relevant factual elements, in particular the duration and regularity of the deceased's presence in the State concerned and the conditions and reasons for that presence". However, Recital 24 of the Preamble admits that habitual residence may be difficult to prove, and can rais problems to the extent that it allows some room for manipulation. The escape clause in Article $21(2)^{2}$ facilitates the finding of the 'proper law' by giving relevance to the law of the State with which the deceased was more closely connected. Recital 25 of the Preamble explains that in

The Regulation No 650/2012 of the European Parliament and of the Council (4 July 2012) on jurisdiction, applicable law, recognition and enforcement of decisions and acceptance and enforcement of authentic instruments in matters of succession and on the creation of a European Certificate of Succession (hereinafter referred to as the EU Succession Regulation)

2 "Where, by way of exception, it is clear from all the circumstances of the case that, at the time of death, the deceased was manifestly more closely connected with a State other than the State whose law would be applicable under paragraph 1, the law applicable to the succession shall be the law of that other State." 
exceptional cases - where, for instance, the deceased had moved to the State of his habitual residence fairly recently before his death and all the circumstances of the case indicate that he was manifestly more closely connected with another State - courts are entitled to arrive at the conclusion that the law applicable to the succession should not be the law of the State of the habitual residence of the deceased. However, as 25 Recital of the Preamble stresses out, the „manifestly closest connection should, however, not be resorted to as a subsidiary connecting factor whenever the determination of the habitual residence of the deceased at the time of death proves complex".

As it follows from Article 22, citizens are entitled to choose the law applicable to their succession. Article 22 (1) limits this choice to the law of a State of their nationality ${ }^{3}$. As Recital 38 of the Preamble stresses out this limitation ensures a connection between the deceased and the law chosen and aims to avoid a law being chosen with the intention of frustrating the legitimate expectations of persons entitled to a reserved share. Article 22 (2) rules furthermore that the choice of law should be made expressly in a declaration in the form of a disposition of property upon death or be demonstrated by the terms of such a disposition.

It is Recital 27 of the Preamble that refers the followings „the rules of this Regulation are devised so as to ensure that the authority dealing with the succession will, in most situations, be applying its own law". However, in certain cases, the rules of the Regulation may lead to a situation where the court having jurisdiction to rule on succession will be applying foreign law. In this case, the public policy mechanisms would come into play if the condition of its application are met.

\section{THE PUBLIC POLICY (ORDRE PUBLIC) RULE OF THE EU SUCCESSION REGULATION}

The EU Succession Regulation declares in Article 35 that " $[\mathrm{t}]$ he application of a provision of the law of any State specified by this Regulation may be refused only if such application is manifestly incompatible with the public policy (ordre public) of the forum". Besides it, Article 39 rules that a decision given in a Member State shall be recognised in the other Member States without any special procedure being required, except there is a ground of non-recognition (Article 40). According to Article 40 a) such ground is "if such recognition is manifestly contrary to public policy (ordre public) in the Member State in which recognition is sought". The

„A person may choose as the law to govern his succession as a whole the law of the State whose nationality he possesses at the time of making the choice or at the time of death. A person possessing multiple nationalities may choose the law of any of the States whose nationality he possesses at the time of making the choice or at the time of death." 
same rule applies as ground of non-recognition in case of acceptance of authentic instruments (Article 59), enforceability of authentic instruments (Article 60), enforceability of court settlements (Article 61).

It shall be emphasized that the adopted wording of Article 35 is fully accord with the public policy rule of the Rome I Regulation ${ }^{4}$ (Article 21) and the Rome II Regulation $^{5}$ (Article 26). The public policy rule in the Proposal of the EU Succession Regulation ${ }^{6}$ as the Max Planck Institute for Comparative and International Private Law (hereinafter referred to as the Max Planck Institute) highlighted was based on Article 18 of the Hague Succession Convention ${ }^{7}$. However, the Max Planck Institute expressed the need to adopt the wording of Article 21 of the Rome I Regulation and Article 26 of the Rome II Regulation and reasoned it with the importance of developing consistent rules for general questions of private international law such as public policy. ${ }^{8}$

The wording of Article $35^{9}$ of the EU Succession Regulation makes it clear that the public policy rule can be invoked only after the applicable law had been determined and courts are entitled to deny the application of foreign law only if its application would be manifestly incompatible with the public policy of the forum. Based on the wording of Article 35, that is the expression of "manifestly"

4 Regulation (EC) No 593/2008 of the European Parliament and of the Council of 17 June 2008 on the law applicable to contractual obligations (Rome I) (hereinafter referred to as Rome I Regulation)

5 Regulation (EC) No 864/2007 of the European Parliament and of the Council of 11 July 2007 on the law applicable to non-contractual obligations (Rome II) (hereinafter referred to as Rome II Regulation)

6 Proposal for a Regulation of the European Parliament and of the Council on jurisdiction, applicable law, recognition and enforcement of decisions and authentic instruments in matters of succession and the creation of a European Certificate of Succession, COM(2009) 154 final of 14.10.2009 (hereinafter referred to as the Proposal of the EU Succession Regulation)

7 Convention of 1 August 1989 on the Law Applicable to Succession to the Estates of Deceased Persons is not yet in force. (hereinafter referred to of the Hague Succession Convention)

8 Max Planck Institute for Comparative and International Private Law. Comments on the European Commission's Proposal for a Regulation of the European Parliament and of the Council on jurisdiction, applicable law, recognition and enforcement of decisions and authentic instruments in matters of succession and the creation of a European Certificate of Succession. Comment to Article 27. Rabels Zeitschrift, Bd. 74, No. 3, 2010, p. 663

9 The Proposal of the EU Succession Regulation ruled in Article 22 about the special succession regimes. However, the Max Planck Institute suggested that this rule should be modelled on Article 9 of the Rome I Regulation rather than on Article 15 of the Hague Succession Convention and should be named as overriding mandatory provisions. Finally, Article 22 had been set aside from the Proposal and the adopted version of the EU Succession Regulation does not contain any rule on overriding mandatory provisions 
and the Recital 58 of the Preamble ${ }^{10}$, the narrow interpretation of the text should be supported. ${ }^{11}$ In addition, it is regularly highlighted that the public policy rule shall be applicable only if the case has enough connection to the forum State (Inlandsbezug). ${ }^{12}$

The Max Planck Institute argues that as the Preamble refers to the Charter of Fundamental Rights of the European Union, such an interpretation ${ }^{13}$ is suggested according to which Article 35 is not limited to the mere policies of the forum State, but also encompasses the public policy of the European Union as an integral part of the forum's policies. ${ }^{14}$ So, while deciding about the incompatibility of the foreign law with the law of the forum, the values of European legal tradition, and thus the case law of the Court of Justice of the European Union should be taken into consideration by the courts. Therefore, Article 35 shall be interpreted with the guidance of Recital 81 of the Preamble which says that this Regulation respects the fundamental rights and observes the principles recognised in the Charter of Fundamental Rights of the European Union, and it must be applied by the courts of the Member States in observance of the rights and principles contained in the Charter of Fundamental Rights. A reference to the Charter of Fundamental Rights also appears in Recital 58 of the Preamble. Recital 58 emphasizes that "the courts or other competent authorities should not be able to apply the public-policy exception in order to set aside the law of another State or to refuse to recognise or, as the case may be, accept or enforce a decision, an authentic instrument or a court settlement from another Member State when doing so would be contrary to the Charter of Fundamental Rights of the European Union, and in particular Article 21 thereof, which prohibits all forms of discrimination." Article 21 of the Charter

$10 \quad$ See especially the first sentence of Recital 58: "Considerations of public interest should allow courts and other competent authorities dealing with matters of succession in the Member States to disregard, in exceptional circumstances, certain provisions of a foreign law where, in a given case, applying such provisions would be manifestly incompatible with the public policy (ordre public) of the Member State concerned."

11 As it is suggested in the literature of the Rome I Regulation and the Rome II Regulation, see e.g.: Thorn, K., Art 21 Rom I-VO, in: Rauscher, T. (ed.), Europäisches Zivilprozess- und Kollisionsrecht EuZPR/EuIPR Kommentar, Sellier, München, 2011, p. 586, Renner, M., Rome I Article 21, in :Calliess, G. P. (ed.), Rome Regulations. Commentary, 2nd. ed., Wolters Kluwer, Alphen aan den Rijn, 2015, p. 396,407

12 This is usually mentioned by the commentary literature, see e.g.: Jakob, D.; Picht, P.: Art. 26 Rom II-VO, in: Rauscher, T. (ed.), Europäisches Zivilprozess- und Kollisionsrecht EuZPR/EuIPR Kommentar. Sellier, München, 2011, pp. 1015-1016, Thorn, op. cit., note 11, p. 587

13 It should be noted that as opposed to the Preamble of EU Succession Regulation, the Preamble of the Rome I Regulation and the Rome II Regulation do not refer to the Charter of Fundamental Right

14 Max Planck... Comment to Article 27., op. cit. note 8, p. 663. See also: Renner, op. cit. note 11, p. 399, Burián, L., Európai kolliziós jog: Korszak- és paradigmaváltás a nemzetközi magánjogban? Magyar Jog, Bd. 59, No. 11, 2012, p. 700 
of Fundamental Rights is the so-called non-discrimination rule. Article 21 (1) regulates that "[a]ny discrimination based on any ground such as sex, race, colour, ethnic or social origin, genetic features, language, religion or belief, political or any other opinion, membership of a national minority, property, birth, disability, age or sexual orientation shall be prohibited". Section 2 says that "within the scope of application of the Treaties and without prejudice to any of their specific provisions, any discrimination on grounds of nationality shall be prohibited". Thus, as it is general in the legal systems, that the capacity to inherit is derived from the legal capacity of a person, the non-discrimination rule shall be considered as a core principle when applying the public policy rule.

Finally, it is relevant to mention that the public policy rule of the Proposal of the European Succession Regulation (Article 27) had a second paragraph: "In particular, the application of a rule of the law determined by this Regulation may not be considered to be contrary to the public policy of the forum on the sole ground that its clauses regarding the reserved portion of an estate differ from those in force in the forum". While formulating its opinion about the reserved share of the estate (or other indefeasible rights to the estate), the Max Planck Institute highlighted that there is a danger that the choice of law rules of the Regulation could be circumvented by courts having excessive recourse to exceptions based on public policy ${ }^{15}$ in order to protect the principles of the forum State about mandatory succession rights. The Max Planck Institute also stressed out that only a few Member States considered their national provisions on forced share as an integral part of their respective public policy and also pointed out that the succession laws of many legal systems provide for some kind of compensation of individuals in need. In these situations, it is rather unlikely according to the Max Planck Insitute that a violation of the public policy of the forum would occur, given that the result obtained by the applicable law often does not substantially differ from that of the forum. ${ }^{16}$ The mentioned second paragraph of the public policy rule had been set aside during the adoption of the EU Succession Regulation which can be considered as a reasonable change had to be done. In my view, the formulation of Article 35 still makes it possible to rely on the public policy of the forum in such situations when the applicable law does not provide on whatever legal basis any share from the estate for those individuals who are considered to be entitled to some protection.

\footnotetext{
15 The Max Planck Institute also referred to the „overriding mandatory provisions” as the Proposal of the European Succession Regulation had a separate rule about special succession regimes in Article 22

16 Max Planck... Comment to Article 27., op. cit. note 8. pp. 663-664
} 


\section{PUBLIC POLICY QUESTIONS FROM THE POINT OF THE HUNGARIAN INHERITANCE LAW}

The basis of inheritance law is very much connected to the family law and the property law of a legal order. Therefore, it shall be presumed that public policy also has an important role to protect their values. Based on the rules of the Act V of 2013 on the Civil Code of Hungary (hereinafter referred as "the Hungarian Civil Code") some examples will be discussed hereinafter.

\subsection{Succession, the right of inheritance}

The Hungarian Civil Code guarantees the substantive basis of the right of inheritance by some general rules on succession. These rules are particularly relevant from the point of public policy matters, especially if it is about the violation of the non-discrimination principle. The right to inherit is ultimately based on legal capacity, specifically on section XV of the Fundamental Law of Hungary (25 April 2011) and $\$ 2$ (1) of the Hungarian Civil Code, as these latter rules that the legal capacity of each natural persons is equal.

The right to inherit shall not lapse according to $\$ 7: 2$ of the Hungarian Civil Code. This means that inheritance law claims as property law claims shall not elapse. However, it should be noted that under Hungarian law the reserved (compulsory) share falls under the realm of the law of obligations, thus the period of limitation for claims for reserved share shall be five years $(\$ 7: 76)$.

In addition, $₫ 7: 3$ of the Hungarian Civil Code rules that the disposition of one's property after death may take place by testamentary disposition or by intestate succession. Next to the will, the Hungarian inheritance law accept two other forms of testamentary disposition that are the agreements as to succession ${ }^{17}$ and the testamentary gift ${ }^{18}$. The fact that in a foreign legal system there are different legal basis to inherit, is not enough in itself to call upon for public policy. But e.g.

$17 \quad \$ 7: 48$ [Agreements as to succession]

(1) An agreement as to succession means an agreement where the testator names the other party to the agreement his/her heir in exchange for maintenance, annuity or care to be provided to the testator him/ herself or to a third person specified in the agreement for his entire estate or a specific part thereof, or in respect of certain property, and the other party undertakes the commitment to provide said maintenance, annuity or care

$18 \$ 7: 53$ [Testamentary gift]

(1) If a gift has been given under the condition that the donee outlives the donor, the regulations governing gifts shall apply to the contract with the exception that the formal requirements to be applied shall be the same as those for agreements as to succession

(2) A testamentary gift shall be deemed valid only for a bequest that would qualify as a specific legacy in a will 
if the the foreign law does not allow the disposition of the property at all, or allow but in a discriminatory way, then public policy could come into action.

Here, it also should be noted that in every legal system there are rules which regulate those circumstances based on which a person shall be debarred from succession. One of these is unworthiness. The sole case, that there are different grounds for unworthiness in a foreign legal system, is not sufficient to call upon for public policy. But if the special rule on unworthiness is based on such ground which is discriminatory, then the rule of public policy can help to protect the law of the forum. The same can be said if a foreign law has different rules on the acquisition of inheritance, the legal status of heirs, the estate debts and their satisfaction.

\subsection{Succession by will}

The freedom of testamentary disposition is regulated in $₫ 7: 10$ of the Hungarian Civil Code. It means that the testator shall be entitled to freely dispose of their property, or a part thereof, at time of death by a will. Therefore, as already mentioned above, if someone is debarred from to dispose of their property, then necessarily public policy will come into play. Under Hungarian law, wills shall be drafted in person $(\$ 7: 11)$. This seems to be a second example for a core principle of the Hungarian inheritance law, and is able to generate a debate whether it shall be considered to be part of the Hungarian public policy.

The Hungarian Civil Code contains strict rules on the formal validity requirements for holographic wills ${ }^{19}$ and on attesting a holographic will ${ }^{20}$. The same is

$19 \$ 7: 17$ [Formal validity requirements for holographic wills]

(1) A holographic will shall be considered valid from a formal point of view if the date when it was drafted is clearly indicated, and:

a) if it is entirely written and signed by the testator in his own handwriting;

b) if written by other persons, it is signed by the testator in the contemporaneous presence of two witnesses or, if it was signed previously, the testator declares the signature to be his own before two witnesses in their contemporaneous presence, and if the will is also signed in both cases by the witnesses, indicating their capacity as such; or

c) if written by the testator himself or by other persons, it is signed by the testator, and deposited personally with a notary public either as an open document or a sealed document, specifically marked as a will.

(2) A holographic will written by the testator in his own handwriting, consisting of several separate pages shall be deemed valid if each page is numbered in sequence.

(3) A holographic will consisting of several separate pages, if written by a person other than the testator, shall be deemed valid if each page is numbered in sequence and signed by the testator and by both witnesses.

$20 \$ 7: 18$ [Attesting a holographic will]

(1) A holographic will may not be witnessed by:

a) any person who is unable to verify the testator's identity; 
true when a devise is made to a subscribing witness or another participating per$\operatorname{son}^{21}$. However, the mere fact, that some of these rules are different in a foreign law, it does not raise in itself public policy questions. The rules on joint will or the joint will of spouses ${ }^{22}$ are difficult to value. Such will can be either valid or invalid under national laws. And if it is invalid, spouses are not entitled to execute their will in the same document. It necessarily can only be viewed as a limit of their freedom to testamentary disposition, however, characteristically does not seem to hit the level of public policy. Last but not least, the sole case that there are different grounds for the invalidity and the annulment of a will is not a reason to call for public policy.

\subsection{Intestate succession}

It is a core question in the inheritance law of a legal system that who can be qualified as a legal heir, who is entitled to inherit from the estate. So, the sole case that that there are different types of legal heirs, or different order how they inherit, or different conditions to inherit, or different reasons for debarment, is not enough

b) a minor or incompetent adult, or by any person whose legal capacity has been partially limited in respect of serving as a witness;

c) any person who is illiterate.

(2) The witness' knowledge of the contents of a will and his awareness that he has participated in the drafting of a will are not conditions of the validity of a holographic will.

$21 \$ 7: 19$ [Devise made to a subscribing witness or another participating person]

(1) Any devise made in favour of a subscribing witness of a holographic will or another participating person or one of their relatives shall be invalid, unless this section of the will is handwritten and signed by the testator himself.

(2) A devise made in favour of a subscribing witness or one of his relatives shall not be null and void if two witnesses other than the subscribing witness himself have participated in drafting the will.

(3) The person who drafted, edited or wrote the will, and any person whose activity carries the potential to influence the contents of the will shall be

(4) Where a devise made in favour of a legal person, or any member, executive officer, representative or supervisory board member, or any employee of such legal person may not participate as a witness. Participation by such person in drafting the will shall render the devise made in favor of that legal person invalid.

22 See the rules on joint will in $\$ 7: 23$ of the Hungarian Civil Code:

(1) The wills of two or more persons executed in the same document in any form shall be invalid.

(2) The written will of spouses made during their marriage and executed in the same document shall be considered valid if:

a) it is entirely written and signed by one of the testators in his own handwriting, and the other testator declares in the same document in a signed statement executed in his own handwriting that the document also contains his last will and testament;

b) if written by other persons, it is signed by the testators in the contemporaneous presence of the other testator and the witnesses, or both testators declare separately in the contemporaneous presence of the other testator and the witnesses that the signature on the document is their own; or

c) the spouses made a notarial will 
to call upon for public policy. So, the mere fact that a legal rule or an institution is either unknown in the law of the forum or on the contrary is not present in the foreign law, courts shall not think of applying the public policy rule automatically. But, if these differences are based on such ground which contradicts the nondiscrimination principle, then public policy will necessarily come into play, e.g. the disinheritance of the child born extramarital or the inheritance share of the male and the female children are different.

As far as the succession law status of a child is concerned, in case he/she is not adopted, his/her status can be based only on blood relationship under Hungarian law. The legal effects of a relationship based on lineage is the same, independently whether the child was born in a marriage or extramarital. Such an interpretation that the inheritance rights of these children would not be equal to the children born in a marriage, would be contrary not only to $\$ 7: 55$ (2) of the Hungarian Civil Code, but also to section XV of the Fundamental Law of Hungary and $₫ 2$ (1) of the Hungarian Civil Code, as these latter rules that the legal capacity of each natural persons is equal. Thus, the discrimination of the said children would be contrary to the Hungarian public policy. It should be noted that Hungary is part of the Convention on the Rights of the Child (1989) which rules are based on the underlying principle of the best interests of the child. As already explained above, under Hungarian law, the legal capacity of each natural persons is equal. Thus, if the intestate succession rules discriminate a heir based on their sex (e.g. share of a male son is twice than his sister's one), it would be considered as contrary to the Hungarian public policy.

As far as the succession law status of a partner is concerned, the followings can be highlighted. On the ground of the mere fact, that the inheritance share of a spouse is very limited, it cannot be decided whether it is contrary to the Hungarian public policy or not. For example, under the former Hungarian Civil Code of 1959 the testator' spouse was entitled to the beneficiary ownership (usufruct) all of those assets she/he did not inherit $[\$ 615$ (1)]. In case of the same-sex registered partnership, it can be said that Hungarian law gives the same legal status for a same-sex registered partner as for a spouse from a succession law point of view (both in case of intestate succession and succession by testamentary disposition). ${ }^{23}$ Thus, the said succession law status of the same-sex registered partner shall be part of the Hungarian public policy. In case of the same-sex cohabitation, as it is the situation in case of the opposite-sex cohabitation, it can be said that under Hungarian law the cohabitant is not an heir (intestate succession rules do not relate to them), but

23 See further Fuglinszky, Á., Hungarian law and practice of civil partnerships with special regard to same-sex couples, Cuadernos de Derecho Transnacional. Vol. 9, No. 2, 2017, pp. 278-313 
they can be named as an heir in the will by the testator. ${ }^{24}$ Thus, e.g. if a foreign legal order would give any intestate succession effect to a de facto cohabitant relationship (either opposite-sex or same-sex), the mentioned foreign rules could not be considered as contrasting with the Hungarian public policy. Namely, the mere fact that according to a foreign legal system different person can be qualified as a legal heir e.g. on the ground what is recognized as family relationship, than Hungarian law allows, is not a reason to call upon for public policy. On the contrary, the different notion of family shall be respected. Here, the reference shall be made to the case of Schalk and Kopf v. Austria ${ }^{25}$ and of Pajić v. Croatia ${ }^{26}$, where for the purposes of Article $8^{27}$ of the Convention for the Protection of Human Rights and Fundamental Freedoms, the European Court of Human Rights referred to and reiterated "its established case-law in respect of different-sex couples, namely that the notion of "family " under this provision is not confined to marriage-based relationships and may encompass other de facto "family« ties where the parties are living together out of wedlock".

\section{4. The traditional legal institutions of the Hungarian inheritance law}

The Hungarian inheritance law retained traditional elements from the 19th and the 20th century to the present days. These elements are especially the spouse's life estate, the reserved (compulsory) share of inheritance and the lineal succession. As with the entry into force of the Hungarian Civil Code on 15th March 2014, the spouse's life estate as a general intestate succession status ceased to be exist ${ }^{28}$, hereinafter only the reserved (compulsory) share of inheritance and the lineal succession will be discussed.

\subsubsection{The reserved share of inheritance}

The reserved share of inheritance is an imperative minimum share of the closest relatives and the spouse (or the partner whose legal status is the same or similar

24 See further: Szeibert, O: Marriage and Cohabitation in the New Hungarian Civil Code-Answering the New Challenges, in: Menyhárd, A.; Veress, E. (eds.), New Civil Codes in Hungary and Romania. Springer International Publishing, Cham (Germany), 2017, pp. 173-191

25 Schalk and Kopf v. Austria (Application no. 30141/04) 24 June 2010, p [91]

26 Pajić v. Croatia (Application no. 68453/13) 23 February 2016, p [63]

27 Paragraph 1 of Article 8 rules that "everyone has the right to respect for his private and family life, his home and his correspondence."

28 See $\$ 7: 58$ for the spouse’s share from the estate contemporaneously with a descendant, where paragraph (1) rules that "the testator's spouse shall be entitled contemporaneously with the legal heir to: a) life estate on the family dwelling used together with the testator, including furnishings and appliances, and b) one share of a child from the remainder of the estate." 
to that of the spouse) of the testator chargeable to his/her estate. Legal systems do regulate the reserved share of inheritance either as a proprietary right or as claim based on the law of obligations. As far as the former is concerned, the heir entitled to reserved share shall have the legal status like all other heirs and this hinders the testator to dispose of those parts of his/her estate which is divided und upheld imperatively by the law for the heir entitled to reserved share. In case of the latter, even if the right of the heir entitled to reserved share is infringed by a testamentary disposition or donations given inter vivos, the last will of the testator cannot be avoided and contested, but the heir entitled to reserved share shall be authorized to sue the legal heirs and ask for his/her reserved share of inheritance in the form of a money claim. ${ }^{29}$ The mere fact, that under Hungarian law the reserved share of inheritance falls under the realm of the law of obligations, do not entitle the courts to rely upon the public policy rule if the foreign law regulate the reserved share of inheritance as a proprietary right.

Under Hungarian law, according to the Hungarian Civil Code, the descendants, the spouse (or the same-sex registered partner) and the parents of a testator shall be entitled to a reserved share of inheritance if such person is a legal heir of the testator or would be one in the absence of a testamentary disposition at the time of the opening of the succession $(\$ 7: 75)$. However, if any of the heir entitled to reserved share is validly disinherited by the testator in his/her testamentary disposition, the reserved share will be also denied from him/her ( $\$ 7: 77)$. Disinheritance shall be valid if the testamentary disposition expressly indicates any of the grounds which are listed in $\$ 7: 78(1)^{30}$ and any of the grounds established proved

29 Csöndes, M.; Klasiček, D: The legal nature of the forced share of inheritance under Croatian and Hungarian law in: Drinóczi, T.; Ercsey, Zs.; Zupan, M.; Vinkovic, M. (eds.), Contemporary legal challenges: EU - Hungary - Croatia, University of Pécs Faculty of Law, Pécs-Osijek, 2012, pp. 457-458. See also Klasiček, D., Nužno nasljedno prvo kao ograničenje slobode oporučnog raspolaganja [Imperative Inheritance - Limitation of Freedom of Testatio], doktorska disertacija, Pravni fakultet, Zagreb, 2011

$30 \$ 7: 78$ [Grounds for disinheritance]

(1) Disinheritance can take place if a person entitled to a compulsory share:

a) is undeserving of inheritance from the testator;

b) has committed a serious crime to the injury of the testator;

c) has attempted to take the life of the testator's spouse, domestic partner or his next of kin or has committed another serious crime to their injury;

d) has seriously violated his legal obligation to support the testator;

e) lives by immoral standards;

f) has been sentenced to an executable term of imprisonment, and has not yet served his term;

g) has failed to offer aid or assistance as it may be expected by the testator at a time of need.

(2) The testator may disinherit a descendant of legal age for reasons of gross ingratitude the descendant has displayed toward the testator.

(3) A parent may be disinherited by the testator for wrongful conduct which would also serve grounds for the termination of parental custody rights.

(4) A testator may disinherit his/her spouse because of a conduct seriously violating conjugal rights. 
to be true. Thus, the conclusion is the same, different rules on the reserved share of inheritance under foreign law do not entitle the courts to rely upon the public policy rule.

Recourse to the nature of the reserved share of inheritance, the Constitutional Court of Hungary declared in its decision 1383/B/1990 that the reserved share is not part of the inheritance law protected under Article $14^{31}$ of the Constitution of the Republic of Hungary, thus the reserved share of inheritance is not protected constitutionally. Article XIII (1) of the Fundamental Law of Hungary of 2011 - as the former Consitution - declares everyone's right to succession. Since the entry into force of the Fundamental Law of Hungary (01. 01. 2012) the Constitutional Court of Hungary has not been decided about the constitutional interpretation of the right of inheritance in Article XIII (1) in connection with the reserved share of inheritance. However, an opposite approach and interpretation does not seem probable as the Constitutional Court of Hungary in its decision 22/2012. (V. 11.) $)^{32}$ declared that it will continue to use and refer to all of its decisions made under the Constitution provided that the relevant provisions of the Fundamental Law are essentially the same as those in the previous Constitution and also declared that a deviation from the previous practice requires express justification. Nevertheless, it shall be emphasized that even though the reserved share of inheritance is not protected constitutionally, it does not mean that public policy questions cannot arise in connection therewith, as not the constitutional provisions are the only and ultimate sources for the definition and content of the public policy.

For the application of the public policy rule, the followings shall be emphasized. The Max Planck Institute also suggested the reliance on the public policy rule for such situation where the testator, for example, modifies the connecting factor for the sole purpose of circumventing the provisions on forced heirship of the State to which the case is predominantly connected (fraus legis). Beside that on the basis of the Max Planck Institute implications the public policy rule may also come into effect "whenever the exclusion of the reserved portion or of other indefeasible rights to the estate does not constitute the «sole ground» but is rather intermingled with other elements which creates a fundamental contradiction with the public

(5) Any person who is debarred from succession for reason of disinheritance shall not be entitled to administer the inheritance of the person replacing him. The provisions pertaining to the termination of the parents' asset management right shall apply mutatis mutandis to the administration of such assets

31 Article 14 of the Act XX of 1949 on the Constitution of the Republic of Hungary ruled that "The Constitution guarantees the right of inheritance."

32 Dec. 22/2012 (V. 11.) AB on the interpretation of paras (2) and (4) of Article E) of the Fundamental Law of Hungary, paragraph [40] 
policy of the forum state, e.g. when combined with a discriminatory purpose". The example given to it was the following: if the testator intended to exclude certain persons because of their gender or religion by choosing a foreign law that prevents this group of heirs from participating in the estate. ${ }^{33}$

\subsubsection{The lineal succession}

During the codification of the Hungarian Civil Code the lineal succession were not intended to abolish, and what is more, its main rules from the former Hungarian Civil Code of 1959 were preserved. This is a special form of intestate succession. Assets falling under the rules of linear succession are an independent sub-category of the estate. The lineal succession essentially means that certain properties are returned to the deceased's family if the deceased leaves no children or other descendants, instead of going to the spouse (or the same-sex registered partner). ${ }^{34}$ Namely, if the legal heir is not a descendant of the decedent, any property that has come down to the decedent from an ancestor by inheritance or gift shall be subject to lineal succession [ $\$$ 7:67 (1) of the Hungarian Civil Code]. To underline, the linear succession ensures that any assets belonging to the family of the deceased are returned to their family and the spouses shall be entitled to life estate on the lineal property. ${ }^{35}$ According to $\$ 7: 70$ (2) the provisions on lineal succession shall not apply to any property that no longer exists at the time of the testator's death, however, they shall apply to any substitute property or a property purchased from the proceeds received for such property.

Though, lineal succession was just briefly presented, it is without doubts that as a special form of intestate succession it serves a special policy. That is to hold the property on those parental site from where it has come down to the decedent by inheritance or gift and do not allow its devolution on the basis of the general intestate succession rules to the other parental site or the spouse (or the same-sex registered partner). ${ }^{36}$ Nevertheless, these rules cannot be considered to be part of the Hungarian public policy.

33 The Max Planck Institute made these comments in connection to the not adopted second paragraph of Article 27, however its essence is valid to the present rule of Article 22, as well. See Max Planck... Comment to Article 27., op. cit. note 8. p. 664

34 See also $\$ 7: 67$ (2) on lineal property: "Property inherited or received as a gift from a sibling or his descendant shall also be subject to lineal succession if the property had been inherited or received as a gift by the sibling or his/her descendant from his/her and the decedent's common ancestor."

35 Molnár, H., The Position of the Surviving Spouse in the Hungarian Law of Succession. ELTE Law Journal, Bd 2., No. 2, 2014, pp.96-97. Available at [http://eltelawjournal.hu/wp-content/uploads/2015/12/7_ Hella_Molnar.pdf] Accessed 15.04.2019.

36 To the policy of the lineal succession see: Vékás, L., Öröklési jog (Inheritance law), 7th. ed., Eötvös József Könyvkiadó, Budapest, 2013. pp. 115-117, Fabó, T., Ági öröklés (Lineal succession), in: Oszto- 


\section{SUMMARY}

In this paper it was presented that the question whether a rule of a foreign law could be considered as contrary to the Hungarian public policy can only be answered in the knowledge of the concrete provisions. That is how a judgment can be given about public policy issues.

While deciding about such difficult questions courts are often confronted with another complicated matter. It is well-known that succession law effects are basically based on family law relationship. However, sometimes, first, the existance and the validity of this family law relationship started to be called into question. E.g. as far as the legal status of the spouse is concerned, the question could be whether the marriage was validly concluded or as far as the legal status of the child is concerned, the question could be whether his/her status is based either on blood relationship or on adoption. In private international law it is the so-called preliminary question (Vorfrage). If the preliminary question is solved dependently, then the law designated by the conflict of laws rules on succession will determine not only the substantive law questions of the succession, but also the substantive law questions of those legal relationship which give the basis the succession law effects. However, if the preliminary question is solved independently, then the law designated by the conflict of laws rules of the forum will determine the substantive law questions of those legal relationship which give the basis the succession law effects. ${ }^{37}$ To note, the Act XXVIII of 2017 on private international law does not contain any concrete rule about the preliminary question, therefore it is for the judge to decide whether to solve the preliminary question dependently or independently. If it is solved independently, then public policy questions could become more intensive in the question asked.

\section{REFERENCES}

\section{BOOKS AND ARTICLES}

1. Burián, L., Európai kolliziós jog: Korszak- és paradigmaváltás a nemzetközi magánjogban? Magyar Jog, Bd. 59, No. 11, 2012, pp. 695-704

2. Calliess, G.P. (ed.): Rome Regulations. Commentary. 2nd. ed., Wolters Kluwer, Alphen aan den Rijn, 2015

vits, A. (ed.) Commentary of the Act V of 2013 on Civil Code and the related Acts, Vol. 4, Opten, Budapest, 2014, pp. 651-652

37 Mádl, F.; Vékás, L., Nemzetközi magánjog és nemzetközi gazdasági kapcsolatok joga [Private International Law and the Law of International Economic Relations], $8^{\text {th }}$ ed. ELTE Eötvös Kiadó, Budapest, 2015, pp138-139 
3. Csöndes, M.; Klasiček, D., The legal nature of the forced share of inheritance under Croatian and Hungarian law in: Drinóczi, T.; Ercsey, Zs.; Zupan, M.; Vinkovic, M. (eds.) Contemporary legal challenges: EU - Hungary - Croatia, University of Pécs Faculty of Law, PécsOsijek, 2012, pp. 457-476

4. Fabó, T., Ági öröklés (Lineal succession), in: Osztovits, A. (ed.), Commentary of the Act V of 2013 on Civil Code and the related Acts, Vol. 4. Opten, Budapest, 2014, pp. 651-667

5. Fuglinszky, Á., Hungarian law and practice of civil partnerships with special regard to same-sex couples, Cuadernos de Derecho Transnacional, Vol. 9, No. 2, 2017, pp. 278-313

6. Klasiček, D., Nužno nasljedno prvo kao ograničenje slobode oporučnog raspolaganja [Imperative Inheritance - Limitation of Freedom of Testatio], doktorska disertacija (doctoral thesis), Pravni fakultet, Zagreb, 2011

7. Max Planck Institute for Comparative and International Private Law. Comments on the European Commission's Proposal for a Regulation of the European Parliament and of the Council on jurisdiction, applicable law, recognition and enforcement of decisions and authentic instruments in matters of succession and the creation of a European Certificate of Succession. Rabels Zeitschrift, Bd. 74, No. 3, 2010, pp. 522-720

8. Mádl, F.; Vékás, L., Nemzetközi magánjog és nemzetközi gazdasági kapcsolatok joga [Private International Law and the Law of International Economic Relations], $8^{\text {th }}$ ed. ELTE Eötvös Kiadó, Budapest, 2015

9. Rauscher, T. (ed.): Europäisches Zivilprozess- und Kollisionsrecht EuZPR/EuIPR Kommentar. Sellier, München, 2011

10. Szeibert, O., Marriage and Cohabitation in the New Hungarian Civil Code-Answering the New Challenges, in: Menyhárd, A.; Veress, E. (eds.), New Civil Codes in Hungary and Romania. Springer International Publishing, Cham (Germany), 2017, pp. 173-191

11. Vékás, L., Öröklési jog (Inheritance law), 7th. ed., Eötvös József Könyvkiadó, Budapest, 2013

\section{ECHR}

1. Schalk and Kopf v. Austria (Application no. 30141/04) 24 June 2010

2. Pajić v. Croatia (Application no. 68453/13) 23 February 2016

\section{EU LAW}

1. Regulation (EC) No 864/2007 of the European Parliament and of the Council of 11 July 2007 on the law applicable to non-contractual obligations (Rome II) (2007) OJ L 199

2. Regulation (EC) No 593/2008 of the European Parliament and of the Council of 17 June 2008 on the law applicable to contractual obligations (Rome I) (2008) OJ L 177

3. Regulation No 650/2012 of the European Parliament and of the Council (4 July 2012) on jurisdiction, applicable law, recognition and enforcement of decisions and acceptance and enforcement of authentic instruments in matters of succession and on the creation of a European Certificate of Succession (2012) OJ L 201 


\section{LIST OF NATIONAL REGULATIONS, ACTS AND COURT DECISIONS}

1. Act XX of 1949 on the Constitution of the Republic of Hungary (20 August 1949)

2. Fundamental Law of Hungary (25 April 2011)

3. Act IV of 1959 on the Civil Code of Hungary (1 May 1960)

4. Act V of 2013 on the Civil Code of Hungary (15 March 2014)

\section{WEBSITE REFERENCES}

1. Molnár, H., The Position of the Surviving Spouse in the Hungarian Law of Succession. ELTE Law Journal, Bd 2., No. 2, 2014, pp. 89-105. Available at [http://eltelawjournal.hu/wpcontent/uploads/2015/12/7_Hella_Molnar.pdf] Accessed at 15.04.2019 